of St. Petersburg, the same Academy publishing some two years later his memoir " $\mathrm{U}$ ber einige arktische Trias-Ammoniten des nördlichen Sibirien" (pp. $22 ; 3$ plates). In the same year appeared his work "Über einige japanische Trias-Fossilien" (Beiträge zur Paläontologie und Geologie Osterreich-Ungarns und des Orients, Bd. vii, pp. 163$178 ; 4$ plates). Having published some preliminary remarks on the Cephalopor faunas of the Himalayan Trias in 1892, his "Beiträge zur Kenntnis der obertriadischen Cephalopoden-Faunen des Himalaya" was published by the Vienna Academs in 1896 (Denkschr. d. Kais. Akad. d. Wissensch., math.-naturw. Kl., Btl. lxiii, pp. 575-702; 22 plates), an English translation of the work appearing in 1899 in the Palcentologia Indica (series xr, Himalayan Fossils, rol. iii, part 1).

Probably there is no one to whom we are more indebted for our knowledge of the 'Triassic rocks and of their Cephalopod fannas than to Dr. E. r. Mojsisorics, the zoning of the Triassic rocks being in a very great measure, in fact almost entirely, due to his researehes.

He was the recipient of many honours and distinctions, the University of Cambridge conferring upon him in 1884 the degree of Doctor of Science (honoris cansa). He was also a member of many learned societies, including the Geological Society of London, of which he was elected a Foreign Member in 1893.

\title{
GENERAL SIR RICHARD STRACHEY, R.E., G.C.S.I., LL.D., F.R.S.
}

BoRx J'LY 2t, 1817.

Died Febrtart 12, 1908.

ThIs distinguished officer, who was born at Sutton Court, Somerset, was engaged in important military and engineering works in India from 1836 until 1871. The construction of irrigation works, canals, and railways was varied by active military service, strachey haring taken part in the first Sikh war; but while his energies were concentrated mainly on the practical applications of science, he was greatly interested in botany, meteorology, geology, and physical geography. Thus he utilized his opportunities, when engaged in topographical surveys, of making observations on the glaciers of the borlers of Tibet and on the geologr of the Himalayas; and the results were communicated to the Geological Society and published in rols. vii and $x$ of the Quarterly Journal. He was a member of the Council of the Society during the rears $1853-5$, and again in 1866-7; and President of the Rosal Geographical Society from 1887 to 1889 . During the later years of his life General Strachey served at times on the Council of the India Office.

\section{REV. THOMAS WILKINSON NORWOOD, M.A., F.G.S. Borx 1829. \\ Died Jaxtary 26, 1908.}

The Rev. 'T. W. Norwood, formerly of Cheltenham, and for some years a member of the Cotteswold Naturalists' Club, was appointed Vicar of Wrenbury in Cheshire in 1878. There he remained for twenty-nine years, when he retired to Snaith in Yorkshire, and died January 26th, 1908, at the age of 79 . During his residence in 